\title{
Effects of transforming growth factor $\beta$ s and basic fibroblast growth factor on articular chondrocytes obtained from immobilised rabbit knees $\dagger$
}

Ryuji Okazaki, Akinori Sakai, Toshitaka Nakamura, Naoki Kunugita, Toshiyuki Norimura, Katsumi Suzuki

\begin{abstract}
Objective-To clarify the effects of transforming growth factor $\beta 1$ (TGFß1), TGFB2, and basic fibroblast growth factor (bFGF) on cell proliferation and proteoglycan (PG) synthesis in articular chondrocytes obtained from immobilised rabbit knees.

Methods-The right knees of rabbits were immobilised in full extension for up to 42 days using fibreglass casts. Specimens for histology were stained with safranin $O$. Chondrocytes were isolated from the weight bearing regions of the femur and tibia of the immobilised knees and cultured with combinations of growth factors. Cell proliferation and PG synthesis were determined by ${ }^{3} \mathrm{H}$-thymidine and ${ }^{35} \mathrm{~S}$-sulphate incorporations.
\end{abstract}

Results-Histological study revealed loss of metachromasia in the articular cartilage at seven days, fissuring and cell clusters at 28 days, and loss of cartilage layers 42 days after immobilisation. Radioisotope assay of the chondrocytes revealed no remarkable change in DNA synthesis in the presence of either TGFB1 or TGF 32 alone. bFGF markedly stimulated cell proliferation in specimens obtained 0 to seven days after immobilisation. The combination of either TGFB1 or TGFB2 with bFGF had a synergistic effect, inducing significant increases in DNA synthesis four, seven, and 14 days after immobilisation. PG synthesis by chondrocytes from immobilised joints was not significantly altered by these agents.

Conclusion-TGFB1 or TGFB2 in combination with bFGF exert synergistic effects on cell proliferation in articular chondrocytes obtained from the rabbit knee during the early days after immobilisation by a cast. These results suggest a critical role of cytokine combinations in the development of articular cartilage degeneration after immobilisation.

(Ann Rheum Dis 1996; 55: 181-186)

Transforming growth factor $\beta$ (TGF $\beta$ ) has profound effects on proliferation and matrix production in cartilage cells. Three isoforms of TGF $\beta$ (TGF $\beta 1, T G F \beta 2$, and TGF $\beta 3$ ) are all expressed in chondrocytes, ${ }^{1}$ and seem to form part of the network of cartilage regulatory factors. ${ }^{1}$ Among these three isoforms, TGF $\beta 1$ and TGF $\beta 2$ are potent growth factors and TGF $\beta 2$ is a more active stimulator of chondrogenesis, ${ }^{2}$ proteoglycan (PG) synthesis, ${ }^{34}$ and cell proliferation in vitro. TGF $\beta$ is also believed to have an important role in the repair process of degenerated cartilage in diseases such as osteoarthritis (OA)..$^{5-9}$

There are several reports, however, indicating that the responsiveness of human articular chondrocytes to TGF $\beta$ may depend on the presence of other serum factors, ${ }^{10}$ and TGF $\beta$ provides both up and down regulation of PG and DNA synthesis in cultured articular chondrocytes. ${ }^{6}{ }^{8}$ Basic fibroblast growth factor (bFGF) is known to be a potent mitogen for chondrocytes $^{41112}$ and to stabilise phenotypic expression of cultured chondrocytes in vitro. ${ }^{13}$ bFGF expression by synovial tissues from the osteoarthritic joint is found to be more intense than that by normal synovial tissues. ${ }^{14}$ These cytokines have been shown to act synergistically to stimulate chondrocyte proliferation in vitro. ${ }^{11} 1516$

We have examined cartilage histologically and used a cell culture system of rabbit chondrocytes obtained from knee joints after immobilisation by fibreglass cast fixation for up to 42 days, in order to clarify whether there is a change in responsiveness of articular chondrocytes to TGF $\beta 1, T G F \beta 2$, bFGF, and combinations thereof, during the development of $\mathrm{OA}$.

\section{Materials and methods}

EXPERIMENTAL PROCEDURE

Thirty two male Japanese white rabbits, six months old and weighing approximately $3 \mathrm{~kg}$, were used. A straight wooden splint measuring approximately $220 \times 25 \times 2 \mathrm{~mm}$ was applied to the dorsal aspect of the right leg from the proximal thigh to the distal end of the limb. The splint was tied to the limb by three to six turns of a fibreglass casting tape (Castlight; Alcare, Tokyo, Japan). The right knee joints of the rabbits were securely immobilised in full extension for periods ranging from 0 to 42 days. Six rabbits were used to examine histology; each was killed 0 (not fixed, day 0), four, seven, 14, 28, and 42 days after immobilisation. The other 26 animals were sacrificed 0 , two, four, seven, 14,28 , and 42 days after immobilisation, for chondrocyte studies; two animals were killed at day 0 and four at each of the other time points. 
HISTOLOGICAL EXAMINATION

Frontal blocks of the knee joints, approximately $5 \mathrm{~mm}$ thick, were excised from the weight bearing region of the femur and the tibia. Specimens for histology were fixed with $10 \%$ formalin for one week and decalcified with $0.53 \mathrm{~mol} / 1$ aluminum chloride mixed with hydrochloric acid $8.5 \mathrm{ml}$ and formic acid 5.0 $\mathrm{ml}$ per $100 \mathrm{ml}$ solution at $4^{\circ} \mathrm{C}$ for 48 hours. Specimens were neutralised with $5 \%$ sodium sulphate at $4^{\circ} \mathrm{C}$ for 48 hours and were embedded in paraffin. Sections $7 \mu \mathrm{m}$ thick were stained with safranin $\mathrm{O}$.

CHONDROCYTE CULTURE AND DETERMINATION OF CYTOKINE CONCENTRATIONS TO BE USED Chondrocytes were obtained from the weight bearing region of the femur bicondyle and tibia of the right knee in animals that had undergone immobilisation. In the animals sacrificed at day 0 , chondrocytes were obtained from both the right and the left knees. Each cartilage sample was cut into small pieces with a scalpel. All pieces of cartilage tissues were mixed together; they were then digested with EDTA, trypsin, and collagenase as described previously. ${ }^{17}$ Cells were seeded at a density of $1 \times 10^{5}$ cells/dish $\left(9.6 \mathrm{~cm}^{2}\right)$ in collagen coated dishes (Corning, Iwaki Glass, Tokyo, Japan); this density was optimal for measuring incorporation of ${ }^{3} \mathrm{H}$-thymidine $\left({ }^{3} \mathrm{H}-\mathrm{TdR}\right)$ into DNA. Cells were cultured in HAM F-12 medium (Gibco, Grand Island, USA) supplemented with $10 \%$ heat inactivated $\left(56^{\circ} \mathrm{C}, 30\right.$ minutes) fetal bovine serum (FBS) (Gibco), $100 \mathrm{U} / \mathrm{ml}$ penicillin, and $100 \mathrm{mg} / \mathrm{ml}$ streptomycin at $37^{\circ} \mathrm{C}$ in a humidified atmosphere of $95 \%$ air and $5 \%$ carbon dioxide, after which $0.5 \mathrm{ng} / \mathrm{ml} \mathrm{TGF} \beta 1$ (Wako, Osaka, Japan), $0.5 \mathrm{ng} / \mathrm{ml}$ TGF $\beta 2$ (Austral Biologicals, USA), $10 \mathrm{ng} / \mathrm{ml} \mathrm{bFGF}$ (donated by Kaken Pharmaceutical Co, Ltd, Tokyo, Japan), and various combinations of these, were added. Conditioned medium was changed after three days, and at the same time cytokines were added. No agents were added to the control at any time. Twelve dishes of cells were prepared to assay each concentration of the agents.

To determine those concentrations, the concentration-response curves were obtained
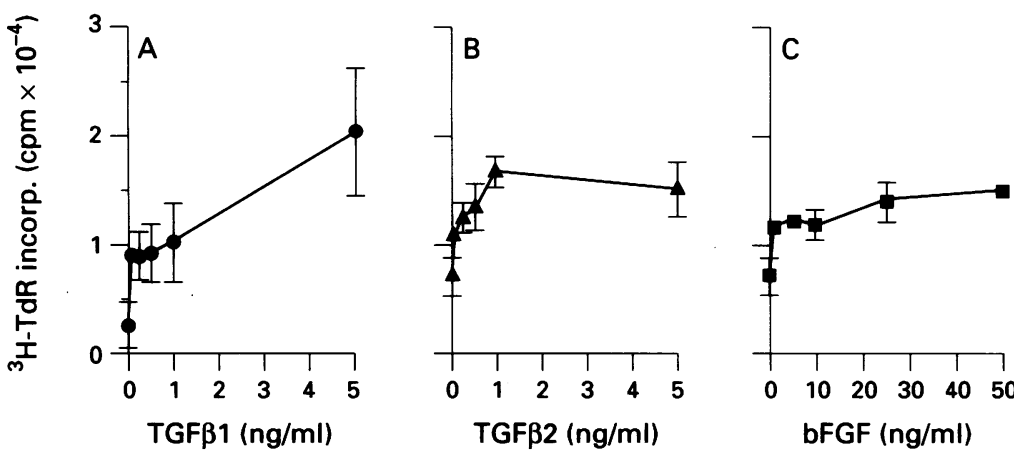

Figure 1 Effects of increasing concentrations of transforming growth factors $\beta 1$ and $\beta 2$ (TGF $\beta 1, T G F \beta 2$ ), and basic fibroblast growth factor (bFGF) on the growth (measured a incorporation of ${ }^{3} \mathrm{H}$-thymidine) of normal rabbit articular chondrocytes, incubated for six days after isolation, in culture with $(\boldsymbol{A}) T G F \beta 1,(B) T G F \beta 2$, or bFGF (C). Four knees used for all experiments; five dishes analysed for each concentration. cpm $=$ Counts per minute: means and $1 S D$ shown. in preliminary experiments. Briefly, articular chondrocytes were obtained from four knees of normal six month old rabbits and cultured in a manner similar to that described above. Chondrocytes were cultured for six days after isolation and incubated in medium containing a concentration of up to $5 \mathrm{ng} / \mathrm{ml}$ for TGF $\beta 1$ and TGF 32 , and up to $50 \mathrm{ng} / \mathrm{ml}$ for bFGF. Six hours before the end of the incubation, ${ }^{3} \mathrm{H}-\mathrm{TdR}$ was added to the culture medium. Concentration-response curves were obtained from the average values of five dishes for each concentration (fig 1). We also obtained the concentration-response curves for ${ }^{35} \mathrm{~S}$-sulphate incorporation (data not shown). Based on these two concentration-response curves, 0.5 $\mathrm{ng} / \mathrm{ml}$ concentrations for TGF $\beta 1$ and TGF $\beta 2$ and a $10 \mathrm{ng} / \mathrm{ml}$ concentration for bFGF were selected.

\section{ASSESSMENTS}

Cell proliferation-Cell proliferation was assayed by incorporation of ${ }^{3} \mathrm{H}-\mathrm{TdR}$ (Amersham Japan, Tokyo, Japan) into chondrocyte DNA. Six dishes were cultured for six days before measurement and then ${ }^{3} \mathrm{H}-\mathrm{TdR}$ was added to each dish at a concentration of $37 \mathrm{kBq}$. After incubation for six hours at $37^{\circ} \mathrm{C}$, each dish was washed with cold phosphate buffered saline three times, 5\% trichloroacetic acid (Wako, Osaka, Japan) once, and ethyl alcohol-diethyl ether $(3: 1, v / v)$ once. Cells were then harvested using a $0.3 \mathrm{~mol} / \mathrm{l}$ solution of sodium hydroxide. The cell suspension thus obtained was filtered through a cellulose acetate filter $(0.45 \mathrm{~mm}$ in diameter) (Sartorius, Göttingen, Germany). After neutralisation, radioactivity bound to the filter was determined by a liquid scintillation counter (LS7000 Liquid Scintillation System, Bechman, Fullerton, USA).

$P G$ synthesis-Six other dishes were cultured for seven days for incorporation of ${ }^{35} \mathrm{~S}$-sulphate (Amersham Japan) as described previously. ${ }^{17}$ ${ }^{35} \mathrm{~S}$-sulphate was added at a concentration of $74 \mathrm{kBq}$ per dish. After incubation at $37^{\circ} \mathrm{C}$ for four hours, each sample was separated into a solution layer and a cellular layer. For the solution layer, calcium chloride dihydrate with Tris- $\mathrm{HCl}$, chondroitin sulphate, magnesium sulphate, and cetylpyridinium chloride were added to each sample. The cell layer was treated in the same way, but after nuclease free protease had been added. After filtration through a cellulose acetate filter, radioactivity bound to the filter was determined by liquid scintillation counting.

\section{STATISTICAL ANALYSIS}

Data are expressed as radioactivity (counts per minute: cpm) and their relative ratios to the mean of the control without agent at each time point. All values are expressed as the mean and 1SD. To assess differences between the control without agent and specimens treated with cytokines, all values were initially assessed by two factor factorial analysis of variance. When a significant difference was found among groups over the time course of the experiments, 

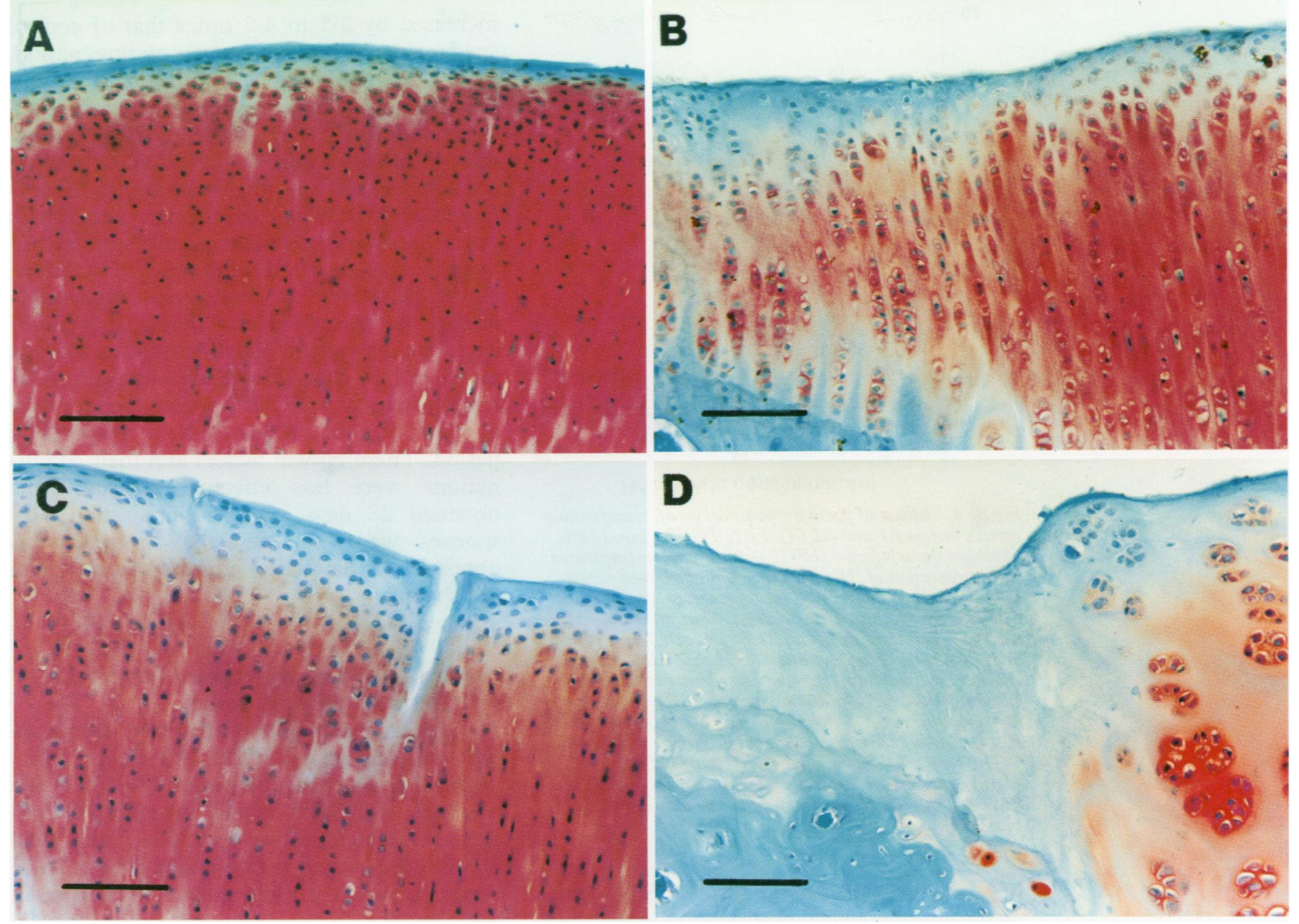

Figure 2 Histological changes in the articular cartilage obtained from rabbit proximal tibia after immobilisation. A: Control (day 0); B: 14 days after immobilisation; $C: 28$ days after immobilisation; D: 42 days after immobilisation. Bar represents $0.1 \mathrm{~mm}$.

values at each time point were compared by Scheffé's $F$ test. A value of $p$ less than 0.05 was considered significant.

\section{Results}

HISTOLOGICAL CHANGES

The tibia specimens at day 0 showed a normal appearance of the articular cartilage with a

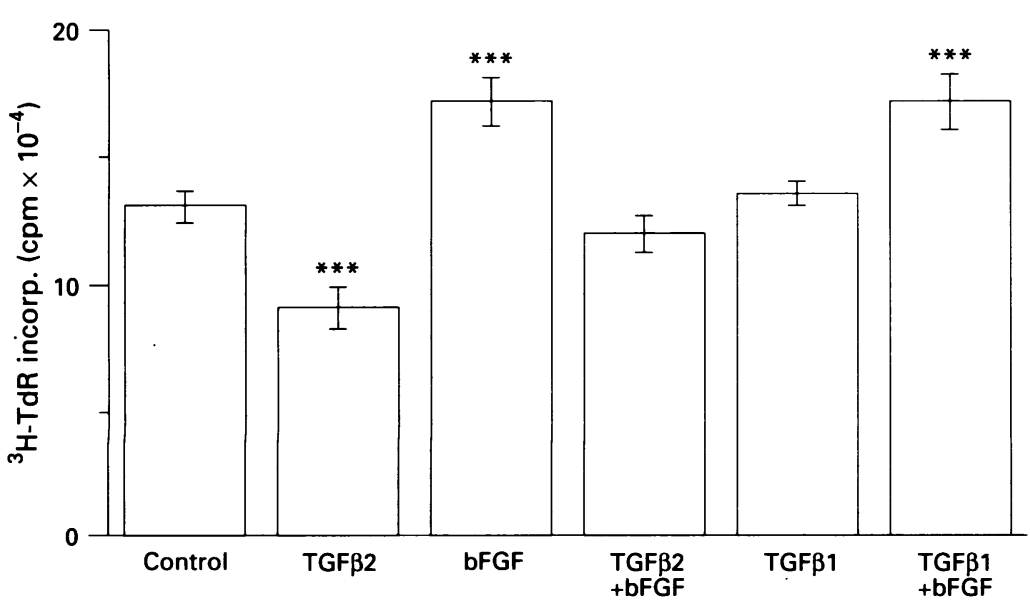

Figure 3 Effects of various combinations of transforming growth factors $\beta 1$ (TGF $\beta 1$ ) $0.5 \mathrm{ng} / \mathrm{ml}$, transforming growth factor $\beta 2$ (TGF 32$) 0.5 \mathrm{ng} / \mathrm{ml}$, and basic fibroblast growth factor (bFGF) $10 \mathrm{ng} / \mathrm{ml}$ on the growth (measured as incorporation of ${ }^{3} \mathrm{H}$-thymidine) of normal rabbit articular chondrocytes incubated in culture with the cytokine combinations for six days after isolation. Four knees used for all experiments; six dishes analysed for each agent. $c p m=$ Counts per minute: means and $1 S D$ shown. ${ }^{\star \star *} p<0.001$ (Scheffé's $F$ test). smooth joint surface, regular cartilage cell columns, and good staining of matrix metachromasia (fig 2A). The joint surface became less smooth and appeared to be undulated in specimens obtained seven to 14 days after immobilisation (fig 2B); loss of metachromasia was also observed in the specimens obtained during this period. In specimens taken 28 days after immobilisation, irregularity of cell columns, cluster formation, and fissures in the cartilage were evident (fig 2C). Forty two days after immobilisation, ulceration of joint surfaces appeared and a cluster formation of the cartilage cells had progressed (fig 2D); a decrease in cartilage cell numbers and nuclear pyknosis were also observed.

EFFECTS OF TGF $\beta 1$, TGF $\beta 2$, bFGF AND THEIR COMBINATIONS ON THE PROLIFERATION OF CHONDROCYTES

At day 0, TGF $\beta 2$ significantly reduced DNA synthesis (by approximately $30 \%$ ) in the chondrocytes obtained from knee joints compared with the control (fig 3), and bFGF significantly increased the values (by approximately $30 \%$ ), but administration of TGF $\beta 1$ did not have any effect on chondrocyte proliferation. No synergistic effect was observed by their combination.

Seven days after immobilisation, chondrocytes from the immobilised knees showed significantly enhanced DNA synthesis in the 


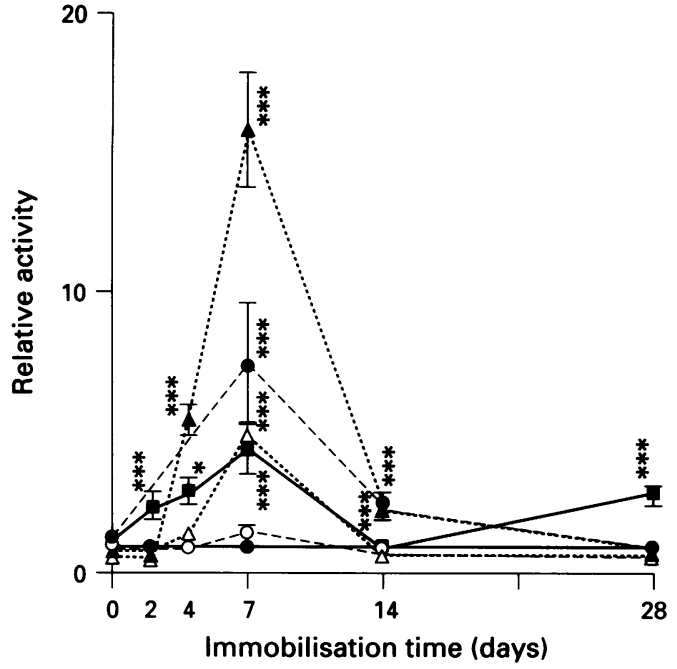

Figure 4 Effects of various combinations of transforming growth factors $\beta 1$ and $\beta 2$ (TGFB1, TGF $\beta 2$ ), and basic fibroblast growth factor (bFGF) on the growth (measured by incorporation of ${ }^{3} \mathrm{H}$-thymidine) of immobilised rabbit knee articular chondrocytes, incubated in culture with the cytokines for six days after isolation. Four rabbit knees for each time point; six dishes analysed for each agent. Relative activity $=$ ratio of incorporation of ${ }^{3} \mathrm{H}$-thymidine into cultures obtained from the immobilised knee to that into cultures from control knees: means and $1 S D$ shown.

$=$ Control; $\triangle=0.5 \mathrm{ng} / \mathrm{ml}$ TGF $\beta 2 ; \quad \square=10 \mathrm{ng} / \mathrm{ml} b F G F$; $\Delta=0.5 \mathrm{ng} / \mathrm{ml} \mathrm{TGF \beta 2}+10 \mathrm{ng} / \mathrm{ml} \mathrm{bFGF} ; 0=0.5 \mathrm{ng} / \mathrm{ml}$ $T G F \beta 1 ; 0=0.5 \mathrm{ng} / \mathrm{ml}$ TGF $\beta 1+10 \mathrm{ng} / \mathrm{ml}$ bFGF Significant differences compared with control: ${ }^{*} p<0.05$; ${ }_{* *}^{*} p<0.001$ (Scheffe's $F$ test after two way analysis of variance).

presence of TGF $\beta 2$ alone (fig 4). bFGF significantly stimulated cell proliferation in the specimens two, four, seven, and 28 days after immobilisation: relative activities were significantly

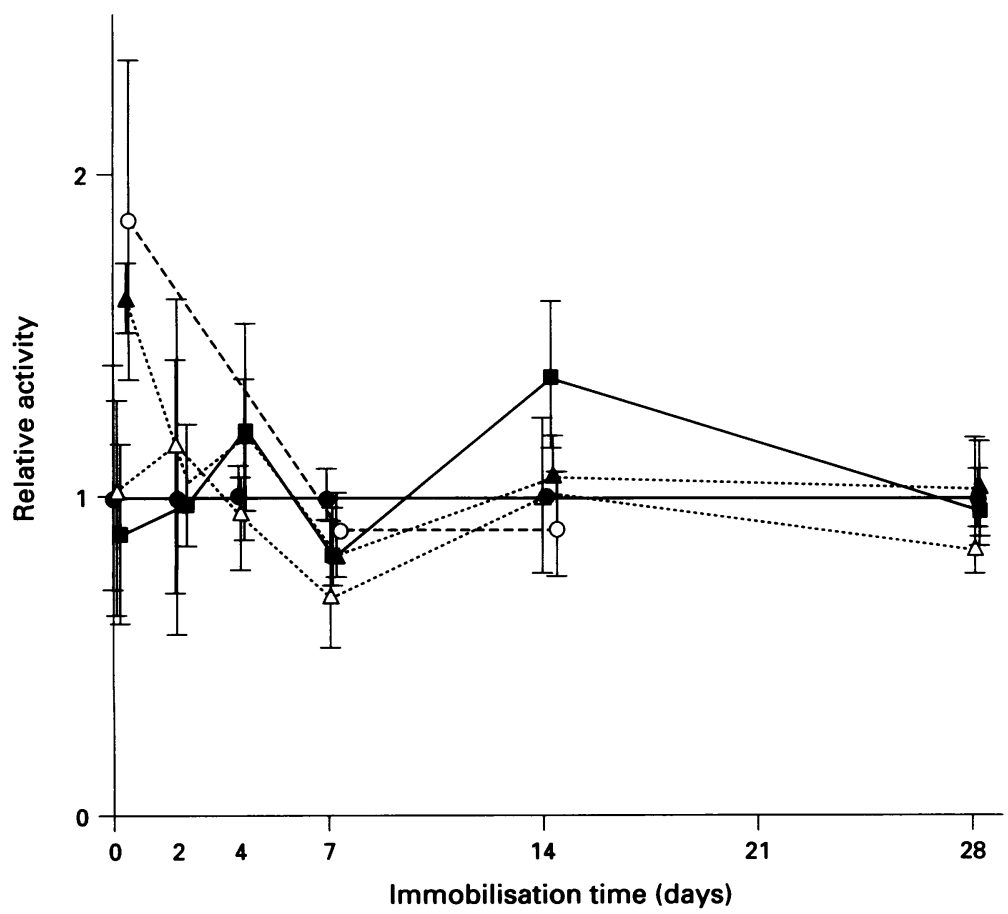

Figure 5 Effects of various combinations of transforming growth factor $\beta 1$ (TGF $\beta 1$ ) $0.5 \mathrm{ng} / \mathrm{ml}$, transforming growth factor $\beta 2$ (TGF $\beta 2$ ) $0.5 \mathrm{ng} / \mathrm{ml}$, and basic fibroblast growth factor (bFGF) $10 \mathrm{ng} / \mathrm{ml}$ on PG synthesis (measured as incorporation of ${ }^{35} \mathrm{~S}$-sulphate) in immobilised rabbit knee articular chondrocytes incubated in culture with the cytokines for seven days after isolation. Four knees for each time point; six dishes analysed for each agent. Relative activity $=$ ratio of incorporation of ${ }^{35} S$-sulphate into cultures obtained from immobilised knees to that into control knees: means and $1 S D$ shown. $O=$ control; $\triangle=0.5 \mathrm{ng} / \mathrm{ml}$ TGF $2 ; \mathrm{D}=10 \mathrm{ng} / \mathrm{ml} b F G F ; \Delta=0.5 \mathrm{ng} / \mathrm{ml}$ TGF $32+10 \mathrm{ng} / \mathrm{ml} b F G F$; $O=0.5 \mathrm{ng} / \mathrm{ml}$ TGF $\beta 1$. Significant increase in $P G$ synthesis in the presence of TGF $\beta 1$ alone, on day 0 . increased by 2.5 to 4.5 times that of control specimens during the corresponding period. The combination of TGF 2 and bFGF exerted a detectable synergistic effect four, seven, and 14 days after immobilisation: relative activities were $5 \cdot 6,15 \cdot 9$, and $2 \cdot 4$ times those in control specimens during the corresponding period. The peak effect of these agents occurred seven days after immobilisation, but decreased 14 days after immobilisation. While TGF $\beta 1$ alone did not induce any remarkable change, the combination of TGF $\beta 1$ and $b F G F$ exerted a synergistic effect on DNA synthesis seven and 14 days after immobilisation: relative activities were 7.5 to 2.5 times greater than in control specimens during the corresponding period. These growth factors and their combinations were less effective in specimens obtained 28 days after immobilisation. Responses were not detected in specimens obtained 42 days after immobilisation (data not shown).

EFFECTS OF TGF 1 , TGFß2, AND bFGF ON PG SYNTHESIS OF CHONDROCYTES

PG synthesis showed no remarkable change in the presence of TGF $\beta 2$, bFGF, or both, during the experimental period (fig 5 ). In the presence of TGF $\beta 1$ alone, however, PG synthesis was significantly increased in normal chondrocytes obtained at day 0 . The relative activities were 1.9 times greater than those in the control.

\section{Discussion}

This study has clearly demonstrated that early changes in the articular cartilage induced by immobilisation are associated with increases in the proliferative response of cartilage cells to bFGF and its combination with TGF $\beta 1$ or TGF $\beta 2$. TGF $\beta 2$ alone was less effective, and TGF $\beta 1$ alone did not induce any significant effect on the chondrocytes. Relative activities of articular chondrocytes in PG synthesis were not changed by these cytokines in this model.

Histological findings confirmed the early degenerative changes such as loss of metachromasia of the matrix and undulation of the cartilage surface starting seven days after immobilisation, and these changes progressed until 14 days after immobilisation (table). Proliferative changes such as cluster formation of the chondrocytes were then found 28 days after immobilisation. Definite cartilage loss was apparent $\mathbf{4 2}$ days after immobilisation. These changes are compatible with previously reported findings of changes in the articular cartilage of rabbit knee joints after immobilisation. ${ }^{18}{ }^{21} \mathrm{It}$ has been reported that incorporation of ${ }^{35} \mathrm{~S}$-sulphate in rabbit knees increases four days after immobilisation, ${ }^{22}$ and that $P G$ synthesis rates increase 10 days or later after immobilisation, ${ }^{19}$ whereas articular chondrocytes in our model did not show increased PG synthesis in response to TGF $\beta 1$, TGF $\beta 2$, or bFGF. Other factors present in the serum, or their combined effects, may have a critical role in the regulation of PG synthesis for articular 
Relationship between histological findings after immobilisation and the effects of various combinations of growth factors on DNA synthesis in cultured articular chondrocytes obtained from immobilised knees

\begin{tabular}{|c|c|c|c|c|c|c|}
\hline & \multicolumn{6}{|c|}{ Immobilisation time (days) } \\
\hline & 0 & 2 & 4 & 7 & 14 & 28 \\
\hline $\begin{array}{l}\text { Histological } \\
\text { findings }\end{array}$ & Normal & No data & $\begin{array}{l}\text { No apparent } \\
\text { change }\end{array}$ & $\begin{array}{l}\text { Loss of metachromasia } \\
\text { Undulated surface }\end{array}$ & $\begin{array}{l}\text { Loss of metachromasia } \\
\text { Undulated surface }\end{array}$ & $\begin{array}{l}\text { Cell clusters } \\
\text { Fissuring } \\
\text { Irregularity of } \\
\text { cell columns }\end{array}$ \\
\hline $\begin{array}{l}\text { DNA synthesis } \\
\text { in presence of } \\
\text { TGF } 2 \\
\text { bFGF } \\
\text { TGF } 22+\text { bFGF } \\
\text { TGF } 1 \\
\text { TGF } 1 \text { 1 + bFGF }\end{array}$ & $\begin{array}{l}0.70^{\star \star \star} \\
1.31^{\star \star \star} \\
0.91 \\
1.04 \\
1.31^{\star \star \star}\end{array}$ & $\begin{array}{l}0 \cdot 67 \\
2 \cdot 46^{\star \star \star} \\
0 \cdot 75 \\
1 \cdot 19 \\
\text { No data }\end{array}$ & $\begin{array}{l}1 \cdot 56 \\
3 \cdot 02^{\star} \\
5 \cdot 55^{\star \star \star} \\
1 \cdot 05 \\
\text { No data }\end{array}$ & $\begin{array}{c}4 \cdot 97^{\star \star \star} \\
4 \cdot 47^{\star \star \star} \\
15 \cdot 93^{\star \star \star} \\
1 \cdot 48^{\star \star} \\
7 \cdot 50^{\star \star \star}\end{array}$ & $\begin{array}{l}0.75 \\
1.09 \\
2.39^{\star \star \star} \\
0.93 \\
2.53^{\star \star \star}\end{array}$ & $\begin{array}{l}0 \cdot 67 \\
2 \cdot 90^{\star \star \star} \\
0 \cdot 90 \\
\text { No data } \\
\text { No data }\end{array}$ \\
\hline
\end{tabular}

DNA synthesis values expressed as the ratio of experiment to control at each time point.

TGF = Transforming growth factor; bFGF = basic fibroblast growth factor.

Significant difference compared with control group at each time point (Scheffés $F$ test): ${ }^{\star} p<0.05 ; \star \star \star p<0.001$.

chondrocytes during immobilisation of the limb. ${ }^{523}$

The stimulation of DNA synthesis by bFGF observed in normal chondrocytes (day 0 ) may be related to the rather large concentration of this cytokine that we used. The preliminary concentration-response curve of ${ }^{3} \mathrm{H}-\mathrm{TdR}$ incorporation to bFGF showed a sharp increase in the activity in response to a concentration of $1 \mathrm{ng} / \mathrm{ml}$, followed by a gradual increase up to $50 \mathrm{ng} / \mathrm{ml}$, so the $10 \mathrm{ng} / \mathrm{ml}$ concentration we subsequently chose to use was apparently close to the maximal effective one. However, ${ }^{3} \mathrm{H}-\mathrm{TdR}$ incorporation in articular chondrocytes obtained from the joint immobilised for two to seven days was significantly increased and greatly exceeded the maximal level of incorporation observed in normal chondrocytes, after which the incorporation subsided. These transient increases in the proliferative response of the cells to the agent were followed by subsequent histological changes indicating increased proliferation of chondrocytes, such as cluster formation. Therefore, while the concentration of the agent may have been pharmacological, it is likely that the transient increase in DNA synthesis as a result of bFGF stimulation was related to changes in the chondrocytes that were caused by immobilisation.

The effects of TGF $\beta 1$ and TGF $\beta 2$ alone on either PG or DNA synthesis were not as remarkable as expected in our experiments. The effect of TGF $\beta 2$ in stimulating DNA synthesis was significant only seven days after immobilisation. The stimulatory effects of these cytokines became significant when combined with bFGF, four to 14 days after immobilisation. Nevertheless, these results do not indicate less important roles for TGF $\beta 1$ and TGF $\beta 2$ in the development of arthritic changes. It has been well documented that there is an increase in both PG synthesis and cell proliferation during the early stage of human $O A,{ }^{24}{ }^{25}$ and the concentration of TGF $\beta$ in the synovial fluid has been reported to be increased. ${ }^{26}$ The amounts of active TGF $\beta$ produced by osteoarthritic cartilage cells are larger than the amounts produced by normal cartilage. ${ }^{6}$ Furthermore, osteoarthritic cartilage seems to be more sensitive to TGF $\beta$ than is normal cartilage, and PG synthesis in response to $\mathrm{TGF} \beta$ administration has been shown to be upregulated in arthritic cartilage. ${ }^{6}$ Therefore
TGF $\beta$ in combination with other cytokines may exert an anabolic effect to repair the chondrocytes damaged by immobilisation. Another possible explanation for the less remarkable action of TGF $\beta$ in our experiments might relate to our use of a smaller concentration of the cytokine $(0.5 \mathrm{ng} / \mathrm{ml})$ than that observed in osteoarthritic joints. While the TGF $\beta$ concentration in osteoarthritic cartilage tissues in humans has been reported to be $0 \cdot 2$ $\mathrm{ng} / \mathrm{mg}^{6}{ }^{6}$ it has also been reported that the mean concentration of active TGF $\beta$ in synovial fluids was as much as $3.8 \mathrm{ng} / \mathrm{ml}$ for osteoarthritic knee joints. ${ }^{26}$ However, the concentrationresponse curves obtained in our study clearly indicated that the concentration we used was sufficient in normal chondrocytes. With these concentrations of TGF $\beta 1$ and TGF $\beta 2$, we could detect the transiently increased DNA synthesis in degenerated chondrocytes. The data suggest, therefore, that the capacity of chondrocytes to respond to combinations of TGF $\beta 1$ with $b F G F$, and TGF $\beta 2$ with $b F G F$, is greatly increased by immobilisation of the joint for seven days.

Our observation of synergistic effects of TGF $\beta$ s and bFGF on DNA synthesis in chondrocytes suggests a critical role of cytokine combinations in the development of OA. It has been reported previously that TGF $\beta$ and bFGF exert synergistic effects on chondrocyte proliferation in vitro. ${ }^{11} 15$ While the action of bFGF on differentiated chondrocytes seems to be limited in vitro, ${ }^{27}$ administration of bFGF in the rabbit joint was shown to promote the repair of cartilage defects in vivo. ${ }^{28}$ As growth factors act through different pathways, ${ }^{16} \mathrm{com}$ binations of growth factors may also exert various actions on the chondrocytes in vivo. In our study, the differences in the magnitudes of synergistic potential on DNA synthesis between combinations of TGF $\beta 1$ with $b F G F$, and TGF 2 with bFGF at each time point (table) may support the specificity of cytokine combinations on proliferative stimulation. Further examination of the effects of TGF $\beta$ s in combination with other cytokines contained in the serum and synovial fluid, such as epidermal growth factor, would be necessary. ${ }^{10}$ As Vivien et al observed that TGF $\beta$ increased proliferation of rabbit articular chondrocytes in cultures containing $10 \%$ fetal calf serum (FCS), while the agent decreased proliferation 
in a medium containing $2 \% \mathrm{FCS},{ }^{10}$ the concentration of these agents used in combination is clearly important.

Other issues affecting the actions of the cytokine combinations in the development of OA include the microenvironment of the chondrocytes and the state of differentiation of the cells. Pressure and regional circulation in the articular cartilage are easily affected by cast fixation of the joint. Thus immobilisation may cause dedifferentiation of the chondrocytes, and the cellular responses to cytokines may be greatly changed. The responses of DNA synthesis in the articular cartilage to cytokines and their combination may differ depending on the time after immobilisation, as shown in our experiment. In other words, our model may be useful in detecting the transient aspects of chondrocyte metabolism during the development of OA, and the augmentation of DNA synthesis of articular chondrocytes by cytokine combinations may be a phenomenon observed only in the early stage of osteoarthritic change.

In conclusion, either TGF $\beta 1$ or TGF $\beta 2$ combined with bFGF exert a synergistic effect on DNA synthesis of the articular chondrocytes obtained from the rabbit knee in the early days after immobilisation with a cast. These results suggest that cytokine combinations such as TGF $\beta$ s and bFGF may have a critical role in the development of cartilage degeneration after immobilisation, and that a model of immobilisation would be useful in studying the metabolic processes of chondrocytes in diseased cartilage.

The authors thank Mr Satoshi Nomoto, MD, Mrs Miyuki Nikaido, and Mrs Hirovo Kakihara for their technical assistance at the University of Occupational and Environmental Health, Kitakyushu, Japan.

1 Villiger P M, Lotz $M$. Differential expression of TGF $\beta$ isoforms by human articular chondrocytes in response to growth factors. F Cell Physiol 1992; 151: 318-25.

2 Joyce $M$ E, Roberts A B, Sporn M B, Bolander M E Transforming growth factor- $\beta$ and the initiation of chondrogenesis and osteogenesis in the rat femur. $7 \mathrm{Cell}$ Biol 1990; 110: 2195-207.

3 Chen P, Carrington J L, Hammonds R G, Reddi A H. Stimulation of chondrogenesis in limb bud mesoderm cells by recombinant human bone morphogenetic protein $2 \mathrm{~B}$ (BMP-2B) and modulation by transforming growth factor $\beta 1$ and $\beta 2$. Exp Cell Res 1991; 195: 509-15.

4 Hill D J, Logan A. Peptide growth factors and their interactions during chondrogenesis. Prog Growth Factor Res 1992; 4: 45-68

5 Galera P, Rédini F, Vivien D, et al. Effect of transforming growth factor- $\beta$ i (TGF- $\beta 1$ ) on matrix synthesis by growth factor- $\beta 1$ (TGF- $\beta 1$ ) on matrix synthesis by monolayer cultures of rabbit articular chondrocytes during the dedi

6 Lafeber F P, Vander Kraan P M, Huber-Bruning O, Vanden Berg W B, Bijlsma J W. Osteoarthritic human cartilage is more sensitive to transforming growth factor $\beta$ than is normal cartilage. Br $\mathcal{F}$ Rheumatol 1993; 32: 281-6.

7 Redini F, Daireaux M, Mauviel A, Galera P, Loyau G, by rabbit articular chondrocytes in response to transforming growth factor- $\beta$ (TGF- $\beta$ ). Biochim Biophys Acta 1991; 1093: 196-206.

8 van der Kraan P, Vitters E, van den Berg W. Differential effect of transforming growth factor $\beta$ on freshly isolated and cultured articular chondrocytes. $\mathcal{F}$ Rheumatol 1992; 19: $140-5$.

9 Vivien D, Boumedienne K, Galera P, Lebrun E, Pujol J P. Flow cytometric detection of transforming growth factor$\beta$ expression in rabbit articular chondrocytes (RAC) in culture-association with S-phase traverse. Exp Cell Res 1992; 203: 56-61.

10 Vivien D, Galera P, Loyau G, Pujol J P Differentia response of cultured rabbit articular chondrocytes (RAC)
to transforming growth factor $\beta$ (TGF- $\beta$ - -evidence for to transforming growth factor $\beta$ (TGF- $\beta$ )-evidence for
a role of serum factors. Eur $\mathcal{F}$ Cell Biol 1991; 54: 217-23.

11 Inoue $\mathrm{H}$, Kato $\mathrm{Y}$, Iwamoto $M$, Hiraki Y, Sakuda M Suzuki F. Stimulation of cartilage-matrix proteoglycan synthesis by morphologically transformed chondrocyte grown in the presence of fibroblast growth factor and transforming growth factor-beta. $\mathcal{F}$ Cell Physiol $1989 ; 138$ 329-37.

12 Kato Y, Iwamoto M, Koike T. Fibroblast growth factor stimulates colony formation of differentiated chondrocytes in soft agar. 7 Cell Physiol 1987; 133: 491-8.

13 Kato Y, Gospodarowicz D. Sulfated proteoglycan synthesis by confluent cultures of rabbit costal chondrocytes grown by confluent cultures of rabbit costal chondrocytes grown in the presence of

14 Nakashima M, Eguchi K, Aoyagi T, et al. Expression of basic fibroblast growth factor in synovial tissues from patients with rheumatoid arthritis: detection by immunohistological staining and in situ hybridisation. Ann Rheum Dis 1994; 53: 45-50.

15 Iwamoto $M$, Sato $K$, Nakashima $K$, Fuchihata $H$ Suzuki F, Kato Y. Regulation of colony formation of differentiated chondrocytes in soft agar by transforming growth factor-beta. Biochem Biophy's Res Commun 1989; 159: $1006-11$.

16 Horton W E Jr, Higginbotham J D, Chandrasekhar S. Transforming growth factor-beta and fibroblast growth Transforming growth factor-beta and fibroblast growth factor act synergistically to inhibit collagen II synthesis
through a mechanism involving regulatory DNA through a mechanism involving regul

17 Sakai A, Suzuki K, Nakamura T, Norimura T, Tsuchiya T Effects of pulsing electromagnetic fields on cultured cartilage cells. Int Orthop 1991; 15: 341-6.

18 Candolin T, Videman T. Surface changes in the articular cartilage of rabbit knee during immobilization. A scanning electron microscopic study of experimental osteoarthritis. Acta Pathol Microbiol Scand [a] 1980; 88: 291-7.

19 Eronen I, Videman T, Friman C, Michelsson J E. Gly cosaminoglycan metabolism in experimental osteoarthrosis caused by immobilization. Acta Orthop Scand 1978; 49: 329-34

20 Langenskiöld A, Michelsson J E, Videman T. Osteoarthritis of the knee in the rabbit produced by immobilization. Attempts to achieve a reproducible model for studies on pathogenesis and therapy. Acta Orthop Scand 1979; 50 $1-14$

21 Trover H. Experimental models of osteoarthritis: a review Semin Arthritis Rheum 1982; 11: 362-74.

22 Videman T, Michelsson JE, Rauhamäki R, Langenskiöld A. Changes in $35 \mathrm{~S}$-sulphate uptake in different tissues in the knee and hip regions of rabbits during immobilization, remobilization and the development of osteoarthritis. remobilization and the developm

23 Vogel K G, Hernandez D J. The effects of transformin growth factor-beta and serum on proteoglycan synthesis by tendon fibrocartilage. Eur 7 Cell Biol 1992; 59. 304-13.

24 Mankin H J, Dorfman H, Lippiello L, Zarins A. Biochemical and metabolic abnormalities in articular cartilage from osteo-arthritic human hips. II. Correlation of morphology with biochemical and metabolic data. f Bone foint Surg Am 1971; 53: 523-37.

25 Thompson R Jr, Oegema T Jr. Metabolic activity of articular cartilage in osteoarthritis. An in vitro study. F Bone foim Surg Am 1979; 61: 407-16.

26 Fava R, Olsen N, Keski-Oja J, Moses H, Pincus T. Active and latent forms of transforming growth factor $\beta$ activity in synovial effusions. 7 Exp Med 1989; 169: 291-6.

27 Guerne P A Sublet A Lotz M. Growth factor responsiveness of human articular chondrocytes: distinct profiles in primary articular chondrocytes. distinct profles in fibroblasts. F Cell Physiol 1994; 158: 476-84

28 Cuevas P, Burgos J, Baird A. Basic fibroblast growth factor (FGF) promotes cartilage repair in vivo. Biochem Biophys Res Commun 1988; 156: 611-8. 